\title{
Process Optimization Studies on Mediated Electrooxidation
}

\author{
T. Raju *, C. Ahmed Basha \\ Central Electrochemical Research Institute, KARAIKUDI-630 006, India
}

Received 2 February 2004; accepted in revised form 20 September 2004

\begin{abstract}
The purpose of optimization consists in establishing suitable values for the operational parameters of a process, in order to achieve the results of that process to the greatest possible advantages. These ideal operating conditions are known as the optimum. The process parameters are current density, temperature, concentration, electrode materials, flow rate, cell voltage, mixing and diaphragm and engineering quantities are like current efficiency, space-time yield, energy consumption, yield and conversion. There are several possible targets in optimization of process and the main aim is to get maximum yield, high current efficiency, high purity and minimum energy consumption for mediated electrochemical oxidation. Mediated electro oxidation or indirect electrosynthesis is a cyclic process involving electrochemical generation of cerium(IV) and uses that agent to effect a chemical reaction. Cerium(IV) has attracted attention in electroorganic synthesis for synthesis of aldehydes and quinones.
\end{abstract}

Keywords: optimization, parameters, mediated electro oxidation, current efficiency, yield, space-time yield.

\section{Introduction}

The ability to optimize or improve a process is dependent upon the ability on controlling the process. The ability to control the process is dependent upon the access to reliable of measurements. Experimental optimization can be carried out in several ways. Most popular is the one-variable (factor)-at-a-time [OFAT] approach. This approach is however extremely inefficient in locating the true optimum factors when interaction effects are present [1].

Multivariable design of experiments is since many years used to overcome the problems with interaction effects. There are two general groups of experimental designs to choose from sequential or simultaneous experiment designs. The choice depends on the purpose of the study or work [2-3].

The oxidation of organic compounds can be brought about either by a direct electrochemical route or by an indirect route. The direct route is based on direct

\footnotetext{
* Corresponding author. E-mail address: rajuorganic@yahoo.co.in
} 
electron transfer from the organic substrate to the anode. The indirect route employs an intermediate inorganic redox couple. This indirect electrochemical route is called "mediated electro oxidation". In mediated system the concentration of the electro-active species is the major parameter that determines the maximum feasible current density, space-time yield and current efficiency. The amount of charge passed is normally proportional to the concentration and therefore the concentration of electro-active species will also be as high as possible [4-6].

In mediated system, the redox couple readily reacts at the electrode surface and avoid mass transfer problems. Oxidation is brought about by homogenous reaction with the organic compound present in a dissolved or emulsified state. The regeneration of the redox species being carried out by is in-situ or ex-stiu electrochemical method. These mediated electrochemical oxidations have been supported with various inorganic redox couples in which the regeneration of redox couple is carried out in an electrochemical cell [7-10].

The use of oxidizing agents such as chromic acid and manganese dioxide have been known by the chemical industry for many decades [11-16]. In more plentiful times the spent oxidizing solution was discarded on completion of the reaction and only the desired product isolated. Today, as materials become more valuable and the cost of discarding waste increases, the recovery of spent materials such as oxidizing agents becomes more attractive.

For most of the organic oxidations, the preferred acid concentration is between 1 and 4 molar methanesulphonic acid. In this region the solubility of cerium(III) in methanesulphonic acid is about 10 times greater than in the sulphuric acid. This acid concentration gives a higher current efficiency and low energy consumption [17-22] for mediated electroxidation process in methanesulphonic acid medium. Mediated or indirect electroxidation is a cyclic process involving electrochemical generation of redox agent and it uses that agent to affect a chemical oxidation reaction. In this study, a redox mediator "cerium(IV)" is generated from cerium(III) in an electrochemical cell and it can be used in the subsequent synthesis of aromatic aldehydes and quinones.

\section{Experimental}

Solutions of cerous methane sulphonate in methane sulphonic acid were prepared by using cerium carbonate and methane sulphonic acid and this method was described elsewhere [8-12]. Batch type electrochemical cell was used for the electro oxidation of cerous methane sulphonate to ceric methanesulphonate at a current density of $5 \mathrm{~A} / \mathrm{dm}^{2}$ at $50{ }^{\circ} \mathrm{C}$ temperature.

A rectangular PVC tank cell was used as an electrochemical cell with "Nafion" membrane as diaphragm was used for the mediated electro oxidation reaction. The anode and cathode were DSA-O ${ }_{2}$ (mesh type) and stainless steel, respectively. Both the anolyte and catholyte chamber were maintained at a constant temperature of $50{ }^{\circ} \mathrm{C}$ through out the electrolysis. The electrolysis was carried out under constant current condition with low cell voltage. After the electrolysis, the anolyte solution of cerium (IV) was quantitatively analysed by titration with ferrous ammonium sulphate using Ferrion indicator [4]. 


\section{Results and discussion}

The object of this study is to optimise the process parameters like current density, temperature, concentration, electrode materials, mixing and diaphragm for mediated electrochemical synthesis of ceric methanesulphonate from cerous methanesulphonate using methanesulphonic acid in aqueous medium.

Anode

$$
\begin{aligned}
& 6 \mathrm{Ce}(\mathrm{III})-6 \mathrm{e}^{-} \rightarrow 6 \mathrm{Ce}(\mathrm{IV}) \\
& \mathrm{H}_{2} \mathrm{O} \rightarrow 2 \mathrm{H}^{+}+0.5 \mathrm{O}_{2}+2 \mathrm{e}^{-}
\end{aligned}
$$

Cathode

$$
6 \mathrm{H}^{+}+6 \mathrm{e}^{-} \rightarrow 3 \mathrm{H}_{2}
$$

Overall

$$
\mathrm{Ce}(\mathrm{III})-\mathrm{e}^{-} \rightarrow \mathrm{Ce}(\mathrm{IV})
$$

\section{$[\mathrm{A}] \quad[\mathrm{B}]$}

Scheme 1. Mediated electrochemical oxidation system $-\mathrm{Ce}^{3+/ 4+}$

\section{Optimization study by factorial design of experimental parameters}

For many optimization projects in research, development and manufacturing, the sequential simplex design is the method of choice. It is very useful for optimization studies. Experiments are successively performed in a direction of improvement until the optimum is reached. The simplex method can handle many variables with only a few trails, and does not require any assumptions with regard to the underlying model.

In an experiment, to change one or more process variables or factors in order to observe the effect the changes have on one or more response variables. The statistical design of experiment is an efficient procedure for planning experiments so that the data obtained can be analyzed to yield valid and objective conclusions.

The most popular experimental designs are two-level designs. It is ideal for screening designs, simple and economical. It also gives most of the information required to go to a multilevel response surface experiment if one is needed. The standard layout for a two level design uses +1 and -1 notation to denote the 'high level' and 'low level', respectively, for each factor.

Following is the model of matrix for two levels of designs

$\begin{array}{lcc} & \text { Factor } 1\left(\mathrm{x}_{1}\right) & \text { Factor } 2\left(\mathrm{x}_{2}\right) \\ \text { Trail 1 } & -1 & -1 \\ \text { Trail 2 } & +1 & -1 \\ \text { Trail 3 } & -1 & +1 \\ \text { Trail 4 } & +1 & +1\end{array}$

in which 4 trials or runs were conducted with each factor set to high or low during a run according to which the matrix had $\mathrm{a}+1$ or -1 set for the factor 
during that trail. If the experiment had more than 2 factors, there would be an additional column in the matrix for each additional factor. The use of +1 and -1 for the factor settings is called coding the data. This aids in the interpretation of the coefficients fit to any experimental model. After factor settings are coded, center points have the value of ' 0 '.

In factorial design of experiments, the variables whose influence on a particular quantity is being investigated are referred to as factors. The values of these factors, which are set for each experiment, are called levels. For a study of the influence of $\mathrm{n}$ factors at $\mathrm{m}$ levels, $\mathrm{a}^{\mathrm{n}}$ factorial design is employed, $\mathrm{n}$ indicates the number of experiments required.

An example for the use of $2^{2}$ factorial design is the study of the influence of current density, (factor A) and concentration of reactant $\mathrm{C}$ (factor B) on the current efficiency $\phi_{\mathrm{e}}$ of an electrochemical conversion. To each of the two factors (concentration and current density) is assigned a low level $\left(\mathrm{a}_{0}, \mathrm{~b}_{0}\right)$ and high level $\left(a_{1}, b_{1}\right)$. The four values give $2^{2}=4$ combinations of 2 factors. The combinations of parameters are taken as settings for experiments to determine the current efficiency experimentally. The results of the experiments (current efficiency) for each combination of levels are expressed by the following symbols.

\begin{tabular}{|c|c|}
\hline Combination of factor levels & Symbol of the result \\
\hline $\mathrm{a}_{0}, \mathrm{~b}_{0}$ & $(1)$ \\
\hline $\mathrm{a}_{1}, \mathrm{~b}_{0}$ & $\mathrm{a}$ \\
\hline $\mathrm{a}_{0}, \mathrm{~b}_{1}$ & $\mathrm{~b}$ \\
\hline $\mathrm{a}_{1}, \mathrm{~b}_{1}$ & $\mathrm{ab}$ \\
\hline
\end{tabular}

The effect $\mathrm{E}_{\mathrm{A}}$ of factor $\mathrm{A}$ on the result is derived from the difference between the mean values of results for high and low levels of factor A.

$$
\mathrm{E}_{\mathrm{A}}=1 / 2(\mathrm{a}+\mathrm{ab})-1 / 2((1)+\mathrm{b})
$$

The effect of factor B is derived in a similar way:

$$
\mathrm{E}_{\mathrm{B}}=1 / 2(\mathrm{~b}+\mathrm{ab})-1 / 2((1)+\mathrm{a})
$$

Besides these two main effects of the effect factors, there is often an interaction $\mathrm{E}_{\mathrm{AB}}$ between the factors. This is calculated according to the equation:

$$
\mathrm{E}_{\mathrm{AB}}=1 / 2(\mathrm{ab}+(1))-1 / 2(\mathrm{~b}+\mathrm{a})
$$

In the presence of an interaction, the effect of a factor in the region between the lowest and highest levels on the result is inter-related with the level of the other factor. Taking the example of current efficiency, this interaction can also be 
explained physico-chemically. If the polarization curve shows an obvious limiting current region for the reaction under investigation, and if the current density at concentration $\mathrm{C}_{1}$, for example, is always lower than the limiting current density arising from $\mathrm{C}_{1}$, current density has no effect on current efficiency. If, on the other hand, the concentration is reduced to $\mathrm{C}_{0}$, at which value the limiting current density is smaller than the current densities and current efficiency will decrease with increasing current density.

Table 1. Experimental factors for mediated electro oxidation process.

\begin{tabular}{cccc}
\hline experimental factors & $\begin{array}{c}\text { current density } \\
\mathrm{A} / \mathrm{dm}^{2}\end{array}$ & $\begin{array}{c}\mathrm{Ce}(\mathrm{III}) \text { concentration } \\
\mathrm{M}\end{array}$ & $\begin{array}{c}\text { current efficiency } \\
(\%)\end{array}$ \\
\hline$(1)$ & 2 & 0.23 & 55 \\
$(\mathrm{a})$ & 5 & 0.23 & 77 \\
$\mathrm{~b}$ & 2 & 0.68 & 71 \\
$\mathrm{ab}$ & 5 & 0.68 & 97 \\
\hline
\end{tabular}

Table 2. Experimental factor levels for mediated electro oxidation process.

\begin{tabular}{ccc} 
S.No. & combination factor levels & symbol of the result \\
\hline 1 & $\mathrm{a}_{0}, \mathrm{~b}_{0}$ & $(1)$ \\
2 & $\mathrm{a}_{1}, \mathrm{~b}_{0}$ & (a) \\
3 & $\mathrm{a}_{0}, \mathrm{~b}_{1}$ & $(\mathrm{~b})$ \\
4 & $\mathrm{a}_{1}, \mathrm{~b}_{1}$ & $(\mathrm{ab})$ \\
\hline
\end{tabular}

$\bar{X}=$ Mean current efficiency $=75 \% ; \mathrm{E}_{\mathrm{A}}=1 / 2(\mathrm{a}+\mathrm{ab})-1 / 2[1+\mathrm{b}]=29 ; \mathrm{E}_{\mathrm{B}}=1 / 2(\mathrm{~b}+\mathrm{ab})-$ $1 / 2[1+\mathrm{a}]=18 ; \mathrm{E}_{\mathrm{AB}}=1 / 2[\mathrm{ab}+1]-1 / 2(\mathrm{~b}+\mathrm{a})=7$.

$$
\begin{gathered}
Z_{A}=\frac{i-\left(a_{0}+a_{1}\right) / 2}{\left(a_{1}-a_{0}\right) / 2}=\frac{i-(2+5) / 2}{(5-2) / 2}=\frac{i-3.5}{1.5} \\
Z_{B}=\frac{C-\left(b_{0}+b_{1}\right) / 2}{\left(a_{1}-b_{0}\right) / 2}=\frac{C-(0.68+0.23) / 2}{(0.68-0.23) / 2}=\frac{C-0.455}{0.23} \\
\Phi=\bar{X}+\frac{E_{A}}{2} Z_{A}+\frac{E_{B}}{2} Z_{B}+\frac{E_{A B}}{2} Z_{A} Z_{B}
\end{gathered}
$$

The experiments were carried out for the time specified in Table 1 and current efficiency was calculated using factors such as current density and concentration. The empirical equation for current efficiency on mediated electro oxidation has been predicated as follows: 


$$
\Phi=131.19-6.21 \mathrm{i}-83.87 \mathrm{c}+34.96 \mathrm{ic}
$$

\section{Studies on optimum process variables}

Studies have been carried for the optimum parameters for mediated electrochemical oxidation process. Tables 3-9 show the effect of various process parameter results for mediated electrochemical oxidation of cerous methanesulphonate used in batch electrochemical cell. This study revealed that, the optimised process parameters for mediated electrochemical oxidation process are: current density $=5 \mathrm{~A} / \mathrm{dm}^{2}$, temperature $=50{ }^{\circ} \mathrm{C}, \mathrm{Ce}(\mathrm{III})$ concentration $=0.8$ $\mathrm{M}$, stirring rate $=140 \mathrm{rpm}$.

Further studies on electrode materials, $\mathrm{Pt}, \mathrm{Pt} / \mathrm{Ti}, \mathrm{DSA}-\mathrm{O}_{2}$ anodes give high current efficiency. The high solubility of the cerous ion in 2-4 molar methane sulphonic acid enhances the generation of ceric ion concentration with high current efficiency (97\%) at a current density of $5 \mathrm{~A} / \mathrm{dm}^{2}$. The above studies were carried out in a tank type batch electrochemical cell. In that cell, the anolyte was stirred by means of glass stirrer.

\section{Effect of current density}

Table 3 shows the effect of current density on the Ce (III)/Ce (IV) system. The current efficiency for ceric ion generation and conversion of cerous methanesulphonate tends to increase with increasing the current density, and decreases at very high current density, i.e., $15 \mathrm{~A} / \mathrm{dm}^{2}$. At an optimum current density of $5 \mathrm{~A} / \mathrm{dm}^{2}$, the current efficiency and conversion were found to be $97 \%$ and $97 \%$ respectively.

\section{Effect of temperature}

The mediated system reaction was carried out in the temperature range of 30-60 ${ }^{\circ} \mathrm{C}$ in a batch divided cell. Table 4 shows the effect of temperature for mediated electrochemical oxidation system. The current efficiency for $\mathrm{Ce}^{4+}$ formation and the conversion of $\mathrm{Ce}^{3+}$ tend to increase with increasing temperature. The optimum temperature is $50{ }^{\circ} \mathrm{C}$ and this is the ideal temperature for the process development. 
Table 3. Study on the effect of current density.

\begin{tabular}{cccccc}
\hline S.No. & $\begin{array}{c}\text { Current } \\
\text { density } \\
\mathrm{A} / \mathrm{dm}^{2}\end{array}$ & $\begin{array}{c}\text { Temperature } \\
{ }^{\circ} \mathrm{C}\end{array}$ & $\begin{array}{c}\mathrm{Ce}^{3+} \\
\text { moles }\end{array}$ & $\begin{array}{c}\mathrm{Ce}^{4+} \\
\text { moles }\end{array}$ & $\begin{array}{c}\text { Current } \\
\text { efficiency } \\
\%\end{array}$ \\
\hline 1 & 2.5 & 50 & 0.1053 & 0.0800 & 76 \\
2 & 5.0 & 50 & 0.0891 & 0.0864 & 97 \\
3 & 7.5 & 50 & 0.1037 & 0.0860 & 83 \\
4 & 10.0 & 50 & 0.0912 & 0.0538 & 59 \\
5 & 12.5 & 50 & 0.1027 & 0.0575 & 56 \\
6 & 15.0 & 50 & 0.1048 & 0.0586 & 56
\end{tabular}

Anode: DSA - $\mathrm{O}_{2}$; Cathode: stainless steel; Temperature: $50{ }^{\circ} \mathrm{C}$; Anolyte: cerous methanesulphonate; Cell Voltage: 6.3 V; Catholyte: methane sulphonic acid; Stirrer speed: $140 \mathrm{rpm}$.

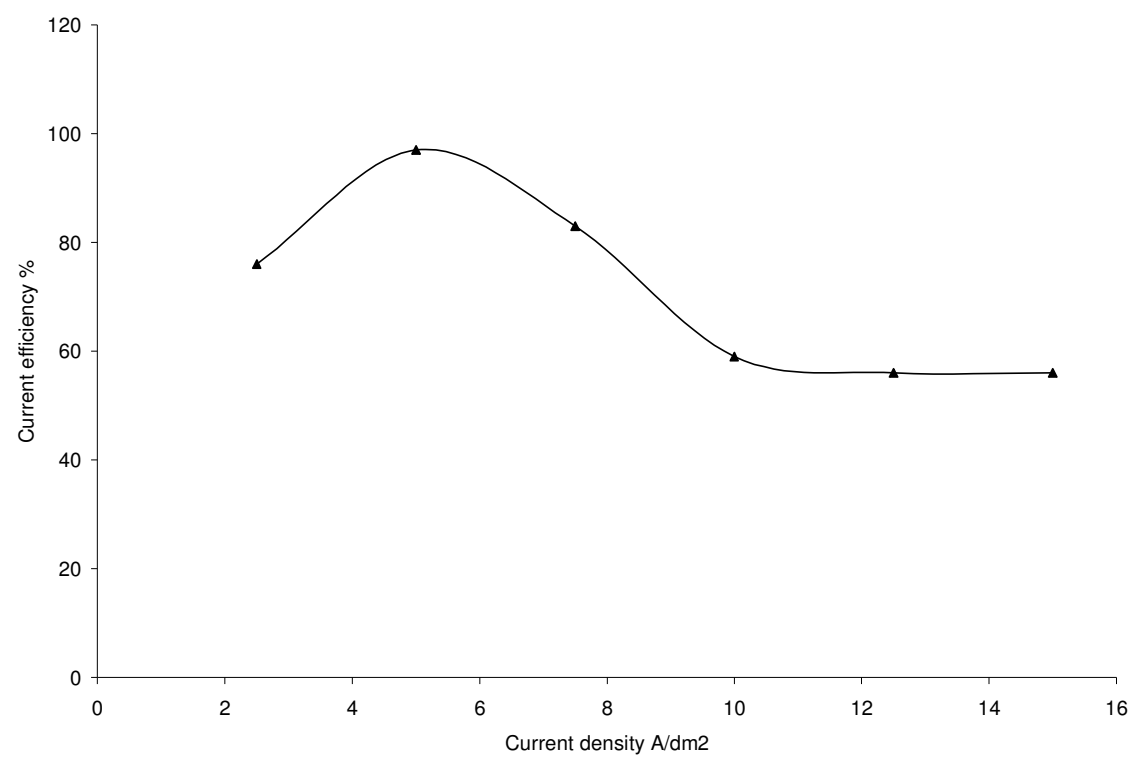

Figure 1. Study on the effect of current density 
Table 4. Study on the effect of temperature

\begin{tabular}{cccccc}
\hline S.No. & $\begin{array}{c}\text { Temperature } \\
{ }^{\circ} \mathrm{C}\end{array}$ & $\begin{array}{c}\text { Current } \\
\text { density } \\
\mathrm{A} / \mathrm{dm}^{2}\end{array}$ & $\begin{array}{c}\mathrm{Ce}^{3+} \\
\text { moles }\end{array}$ & $\begin{array}{c}\mathrm{Ce}^{4+} \\
\text { moles }\end{array}$ & $\begin{array}{c}\text { Current efficiency } \\
\%\end{array}$ \\
\hline 1 & 30 & 2.5 & 0.0904 & 0.0605 & 67 \\
2 & 40 & 2.5 & 0.0912 & 0.0620 & 68 \\
3 & 50 & 2.5 & 0.1053 & 0.0800 & 76 \\
4 & 60 & 2.5 & 0.1031 & 0.0784 & 76 \\
5 & 30 & 5 & 0.0674 & 0.0505 & 75 \\
6 & 40 & 5 & 0.0671 & 0.0566 & 85 \\
7 & 50 & 5 & 0.0679 & 0.0664 & 97 \\
8 & 60 & 10 & 0.0681 & 0.066 & 97 \\
9 & 30 & 10 & 0.093 & 0.0428 & 46 \\
10 & 40 & 10 & 0.0980 & 0.0428 & 53 \\
11 & 50 & 10 & 0.0912 & 0.054 & 59 \\
12 & 60 & 5 & 0.051 & 0.057 & 60 \\
\hline
\end{tabular}

Anode: DSA - $\mathrm{O}_{2}$; Cathode: stainless steel; Anolyte: cerous methanesulphonate; Cell voltage: 4.5V; Catholyte: methanesulphonic acid; Stirrer speed: $140 \mathrm{rpm}$; Diaphragm: nafion membrane.

\section{Effect on agitation of the electrolyte}

The effect of stirring rate of electrolyte was carried out in the range of 75-150 rpm in the electrochemical batch cell. It was observed that the conversion is proceeding with increasing the agitation. It was also observed that the mass transfer for the formation $\mathrm{Ce}^{4+}$ is high in high agitation. The results are presented in Table 5.

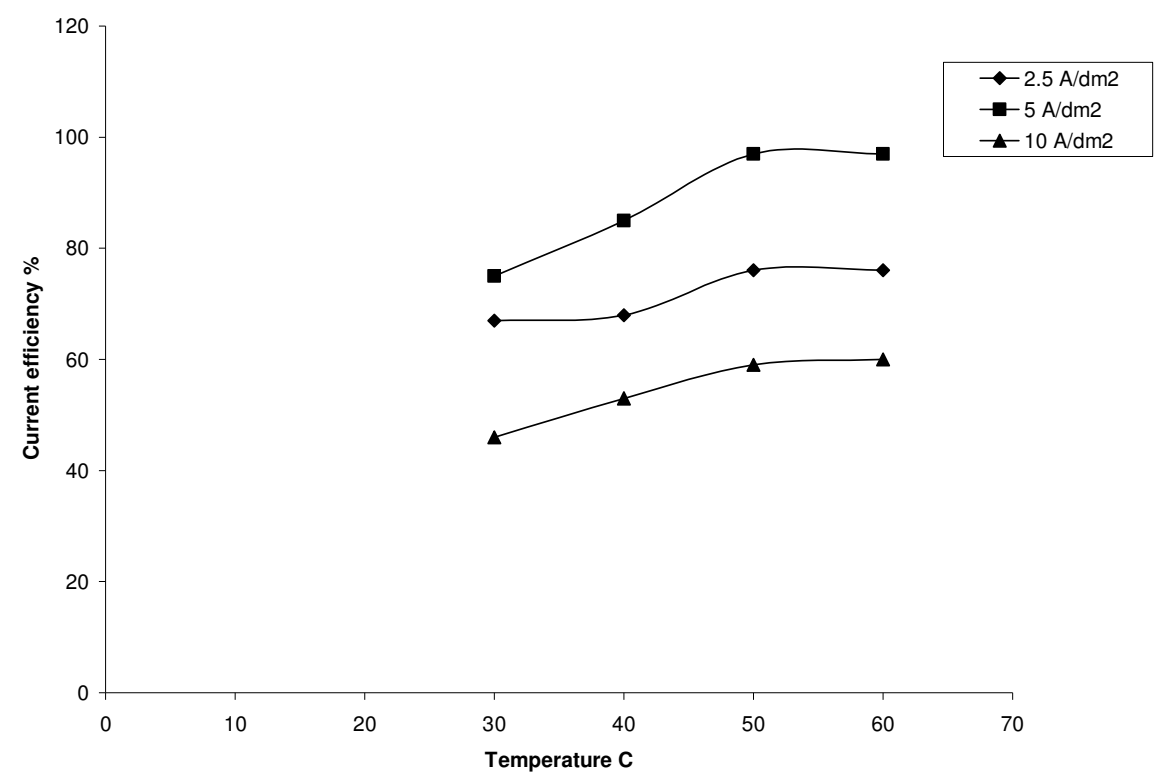

Figure 2. Study on the effect of temperature. 
Table 5. Study on the effect of stirring rate.

\begin{tabular}{ccccc}
\hline S.No. & $\begin{array}{c}\text { Stirrer speed } \\
\text { rpm }\end{array}$ & $\begin{array}{c}\mathrm{Ce}^{3+} \\
\text { moles }\end{array}$ & $\begin{array}{c}\mathrm{Ce}^{4+} \\
\text { moles }\end{array}$ & $\begin{array}{c}\text { Current efficiency } \\
/ \%\end{array}$ \\
\hline 1 & 60 & 0.1075 & 0.0641 & 60 \\
2 & 80 & 0.1070 & 0.0670 & 63 \\
3 & 100 & 0.1034 & 0.080 & 77 \\
4 & 120 & 0.1038 & 0.090 & 87 \\
5 & 140 & 0.1013 & 0.0982 & 97 \\
6 & 160 & 0.1010 & 0.0971 & 97
\end{tabular}

Anode: DSA-O ${ }_{2}$; Current density: $5 \mathrm{amp} / \mathrm{dm}^{2}$; Cathode: stainless steel; Temperature: 50 ${ }^{\circ} \mathrm{C}$; Anolyte: cerous methanesulphonate; Cell Voltage: $3.4 \mathrm{~V}$; Catholyte: methanesulphonic acid; Diaphragm: nafion membrane.

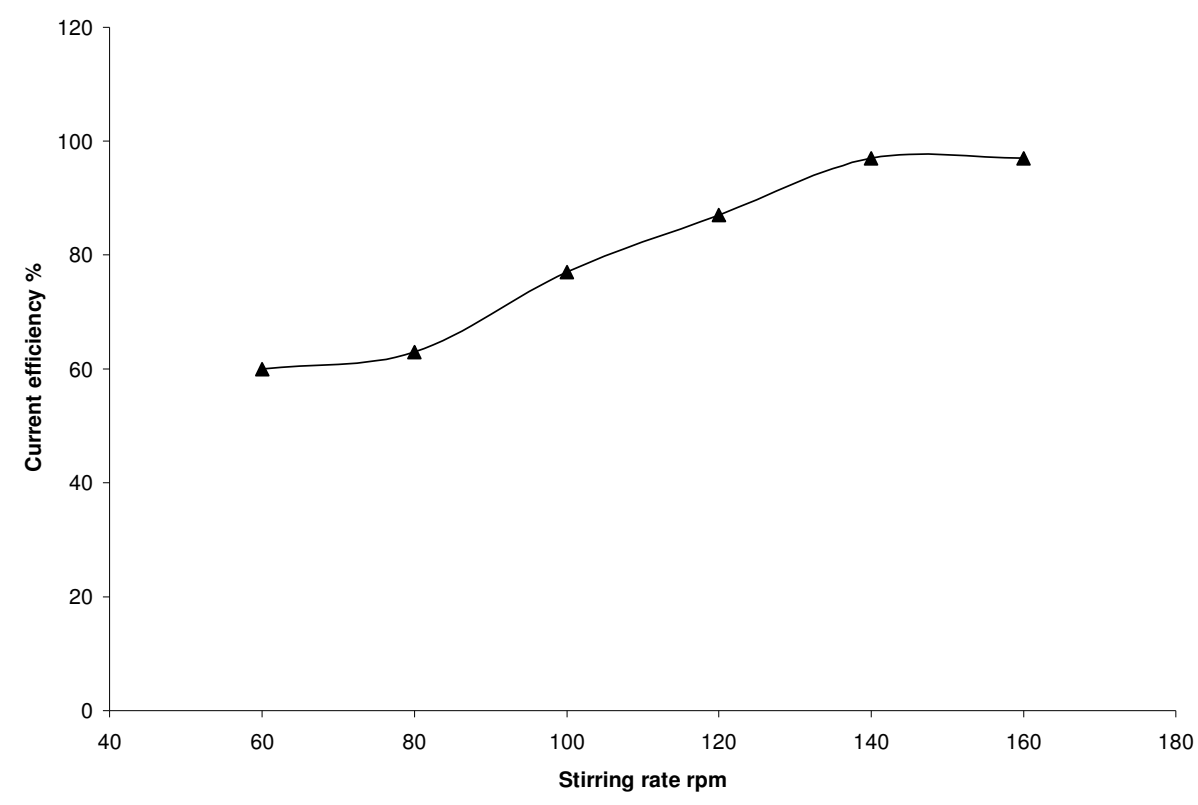

Figure 3. Study on the effect of stirring rate.

\section{Effect of electrolyte concentration}

The effect of $\mathrm{Ce}^{3+}$ concentration was carried out from the range of $0.6 \mathrm{M}$ to 1.0 $\mathrm{M}$ solution. From the experiment, it was revealed that the current efficiency is increased with increase of $\mathrm{Ce}^{3+}$ concentration up to certain concentration and it was also seen that the $\mathrm{Ce}^{4+}$ is precipitated in high concentration of, i.e., 1.0 M to 2.0 M. The results are presented in Table 6. 


\section{Selection of the anode}

The reaction was carried out using $\mathrm{Pt}, \mathrm{Pt} / \mathrm{Ti}, \mathrm{DSA}-\mathrm{O}_{2}$, and graphite anodes for mediated electro oxidation system. The results of the anode selection study for this investigation are presented in Table 7 which compares the performance of the different anodes used.

Table 6. Study on the effect of $\mathrm{Ce}^{3+}$ ion concentration.

\begin{tabular}{lccccc}
\hline S.No. & $\begin{array}{c}\mathrm{Ce}(\mathrm{III}) \\
\text { Electrolyte / } \mathrm{M}\end{array}$ & Anode & $\begin{array}{c}\mathrm{Ce}^{3+} \\
\text { moles }\end{array}$ & $\begin{array}{c}\mathrm{Ce}^{4+} \\
\text { moles }\end{array}$ & $\begin{array}{c}\text { Current } \\
\text { efficiency / \% }\end{array}$ \\
\hline 1 & 0.6 & $\mathrm{DSA}-\mathrm{O}_{2}$ & 0.1041 & 0.0864 & 83 \\
2 & 0.8 & $\mathrm{DSA}-O_{2}$ & 0.1071 & 0.1043 & 97 \\
3 & 1.0 & $\mathrm{DSA}_{2}$ & 0.1340 & 0.1160 & 89 \\
4 & 0.6 & platinum & 0.0991 & 0.0862 & 87 \\
5 & 0.8 & platinum & 0.0983 & 0.0952 & 97 \\
6 & 1.0 & Platinum & 0.0982 & 0.0951 & 97 \\
\hline
\end{tabular}

Cathode: stainless steel; Temperature: $50{ }^{\circ} \mathrm{C}$; Anolyte: cerous methanesulphonate; Cell Voltage: 3.4V; Catholyte: methane sulphonic acid; Stirrer speed:140 rpm; Diaphragm: nafion 400 series; Current density: $5 \mathrm{amp} / \mathrm{dm}^{2}$.

Table7. Study on the selection of the anode.

\begin{tabular}{cccccc}
\hline S.No. & Anode & $\begin{array}{c}\text { Temperature } \\
{ }^{\circ} \mathrm{C}\end{array}$ & $\begin{array}{c}\mathrm{Ce}^{3+} \\
\text { moles }\end{array}$ & $\begin{array}{c}\mathrm{Ce}^{4+} \\
\text { moles }\end{array}$ & $\begin{array}{c}\text { Current } \\
\text { efficiency / (\%) }\end{array}$ \\
\hline 1 & Platinum & 50 & 0.0980 & 0.0950 & 97 \\
2 & $\begin{array}{c}\text { Platinised } \\
\text { titanium }\end{array}$ & 50 & 0.0982 & 0.0951 & 97 \\
3 & DSA-O 2 & 50 & 0.0981 & 0.0950 & 97 \\
4 & Graphite & 50 & 0.0951 & 0.0650 & 69 \\
\hline
\end{tabular}

Cathode: stainless steel; Temperature: $50{ }^{\circ} \mathrm{C}$; Anolyte: cerous methanesulphonate; Cell Voltage: $4.2 \mathrm{~V}$; Catholyte: methane sulphonic acid; Stirrer speed: $140 \mathrm{rpm}$; Diaphragm: nafion 400 series; Current density: $5 \mathrm{~A} / \mathrm{dm}^{2}$.

\section{Selection of the diaphragm}

Diaphragms are used in order to avoid the mixing of anolyte and catholyte, to minimize side reactions. In many cases a reactant may undergo reaction to an undesired product at the auxiliary electrode or the product may interact with the working electrode. The result of the diaphragm selection study is presented in Table 8 . 
Table 8. Study on the effect of the diaphragm.

\begin{tabular}{cccccc}
\hline S.No. & Diaphragm & $\begin{array}{c}\text { Temperature } \\
{ }^{\circ} \mathrm{C}\end{array}$ & $\begin{array}{c}\mathrm{Ce}^{3+} \\
\text { moles }\end{array}$ & $\begin{array}{c}\mathrm{Ce}^{4+} \\
\text { moles }\end{array}$ & $\begin{array}{c}\text { Current } \\
\text { efficiency / (\%) }\end{array}$ \\
\hline 1 & nafion-400 & 50 & 0.1070 & 0.1040 & 97 \\
2 & nafion-350 & 50 & 0.1047 & 0.0920 & 87 \\
3 & nafion-324 & 50 & 0.1075 & 0.1042 & 97
\end{tabular}

Anode: DSA-O ${ }_{2}$; Current density: $5 \mathrm{amp} / \mathrm{dm}^{2}$; Cathode: stainless steel; Temperature: 50 ${ }^{\circ} \mathrm{C}$; Anolyte: cerous methanesulphonate; Cell Voltage: $4.5 \mathrm{~V}$; Catholyte: methane sulphonic acid; Stirrer speed:140 rpm.

\section{Selection of the cathode}

Studies have been carried out for the selection of a suitable cathode material for mediated system. Several cathodes like platinum, graphite and stainless steel were employed for the above system. The results of the cathode selection study are presented in Table 9.

Table 9. Study on the selection of the cathode.

\begin{tabular}{cccccc}
\hline S.No. & $\begin{array}{c}\text { Current } \\
\text { Density / }\left(\mathrm{A} / \mathrm{dm}^{2}\right)\end{array}$ & $\begin{array}{c}\text { Temperature } \\
{ }^{\circ} \mathrm{C}\end{array}$ & $\begin{array}{c}\mathrm{Ce}^{3+} \\
\text { moles }\end{array}$ & $\begin{array}{c}\mathrm{Ce}^{4+} \\
\text { moles }\end{array}$ & $\begin{array}{c}\text { Current } \\
\text { efficiency / (\%) }\end{array}$ \\
\hline 1 & Platinum & 50 & 0.0980 & 0.0950 & 97 \\
2 & Stainless Steel & 50 & 0.1051 & 0.1021 & 97 \\
3 & Graphite & 50 & 0.1030 & 0.0710 & 69
\end{tabular}

Anode: $\quad$ DSA- $\mathrm{O}_{2}$; Temperature: $50{ }^{\circ} \mathrm{C}$; Anolyte: cerous methanesulphonate; Cell Voltage: 4.2V; Catholyte: methane sulphonic acid; Stirrer speed: $140 \mathrm{rpm}$; Diaphragm: nafion 324 series; Current density: $5 \mathrm{~A} / \mathrm{dm}^{2}$.

\section{Conclusion}

The present paper deals with the process of optimization studies for the mediated electro oxidation of $\mathrm{Ce}^{3+}$ to $\mathrm{Ce}^{4+}$ using methanesulphonic acid in aqueous medium and to find out the optimum process parameters for maximum conversion and high current efficiency. The influence of current density, temperature, anode, stirring rate, $\mathrm{Ce}^{3+}$ concentration, are examined in a divided electrochemical cell at constant current electrolysis. These studies are suitable and may be useful for the further scale-up of mediated process.

The following process parameters were optimised for electrochemical synthesis of ceric methanesulphonate in methane sulphonic acid medium.

- current density

- temperature

- $\mathrm{Ce}(\mathrm{III})$ concentration

- anode

- cathode 
- diaphragm

\section{References}

1. R.M. Driver, "Statistical methods and the chemist", Chem. Brit. 6.4 (1970) 154.

2. Walters, Parker, Morgan, "Sequential Simplex Optimization”, CRC Press, 1991.

3. D.C. Montgomery, "Design and Analysis of Experiments", $3^{\text {rd }}$ edn., John Wiley \& Sons, Inc., New York, 1991.

4. D.J. Picket “Electrochemical Reactor Design”, Elsevier, New York (1979) 362-371.

5. F.Goodridge, K. Scott, "Electrochemical Process Engineering", Plenum Press, New York (1995) 14.

6. E. Heitz, G. Kreysa "Principles of Electrochemical Engineering", VCH, New York (1986) 122.

7. D. Pletcher and E.M.Valdes, Electrochim. Acta 33 (1988) 499.

8. K. Krammer, P.M. Robertson and N. Ibl, J. Appl. Electrochem. 10 (1980) 29.

9. H.Wendt and H. Schneider, J. Appl. Electrochem. 16 (1986) 134.

10. G. Kreysa and H. Medin, J. Appl. Electrochem. 16 (1986) 757.

11. J.P. Millington and I.M. Dalrymple, J. Appl. Electrochem. 16 (1986) 885.

12. L. Syper, Tetrahedron Lett. (1966) 4493.

13. M. Periasamy and M.V. Bhatt, Synthesis (1977) 330.

14. M.V. Bhatt and M. Periyasamy, J. Chem. Soc., Perkins Trans. II (1993) 1811.

15. R. Ramasamy, M.S.V. Pathy and H.V.K. Udupa, Bull. Chem. Soc. Japan 35 (1962) 751.

16. V.S. Krishnan, V.A.Vyas, M.S.V. Pathy and H.V.K. Udupa, J. Electrochem. Soc. Japan 37 (1969) 74.

17. R.M. Spotnitz, R.P. Kreh, J.T. Lundquist, R. Press, J. Appl. Electrochem. 20 (1990) 209.

18. R.P. Kreh, R.M. Spotnitz and J.T. Lundquist, Tetrahedron Lett. 28 (1987) 1067.

19. R.P. Kreh, R.M. Spotnitz and J.T. Lundquist, J. Org. Chem. 54 (1989) 1526.

20. R.P. Kreh, R.M. Spotnitz and J.T. Lundquist, in J. David Genders and D. Pletcher, Eds. "Electro Synthesis from Laboratory to Pilot to Production". The Electrosynthesis Company, Inc., E. Amherst, New York (1990) Chapter 10.

21. H. Stephen, US Patent W 09318208 .(1993) Chem.Abstr.120. 199439m (1994)

22. T.Vijayabharathi, D.Velayutham, M. Noel, J. Appl. Electrochem. 31 (2001) 979. 